\title{
Low-Income Black Parents Supporting Their Children's Success through Mentoring Circles
}

\author{
Alana Butler \\ Queen's University
}

\begin{abstract}
This article presents the results of a parent engagement project called "Mentoring Circles." The project focused on the needs of low-income Black parents who have children enrolled in the Toronto District School Board. Two focus groups, with seven to eight Black parents in each group, were conducted during the summer of 2018. The study drew on theories of community wealth and funds of knowledge (González et al., 2005; Yosso, 2005), Black feminist theory (Collins, 2000; Crenshaw, 1991), and critical race theory (Delgado \& Stefancic, 2012). The Black parent narratives served as counter-stories to stereotypes about Black parent disengagement in low-income communities. The low-income Black parents in the study were very engaged in their children's education and were invested in their academic success. The Black parents strategized to support their children's education by forming supportive peer mentoring networks and advocating for their children though
\end{abstract}


relationship-building. The findings suggest that mentoring circles could serve as a model for engaging Black parents in the support of their children's academic success.

Keywords: Black Canadian children and youth, anti-Black racism, Black parents and students, low socio-economic status, race and ethnicity, social class

\section{Résumé}

Les parents noirs à faible revenu soutiennent la réussite de leurs enfants grâce à des cercles de mentorat. Cet article présente les résultats d'un projet d'engagement des parents appelé «Cercles de mentorat ». Le projet s'est concentré sur les besoins des parents noirs à faible revenu ayant des enfants inscrits au Toronto District School Board. Deux groupes de discussion avec 7 à 8 parents noirs ont été organisés au cours de l'été 2018. L'étude s'est inspirée des théories de la richesse communautaire et des fonds de connaissances (González et al., 2005 ; Yosso, 2005), de la théorie féministe noire (Collins, 2000 ; Crenshaw, 1991) et de la théorie critique des races (Delgado et Stefancic, 2012). Les récits des parents noirs ont servi de contre-histoires aux stéréotypes sur le désengagement des parents noirs dans les communautés à faible revenu. Les parents noirs à faible revenu participant à l'étude étaient très engagés dans l'éducation de leurs enfants et investis dans leur réussite scolaire. Les parents noirs ont élaboré une stratégie pour soutenir l'éducation de leurs enfants en formant des réseaux de soutien par les pairs et en défendant leurs enfants grâce à l'établissement de relations. Les résultats permettent de croire que les cercles de mentorat pourraient servir de modèle pour inciter les parents noirs à soutenir la réussite scolaire de leurs enfants.

Mots-clés : enfants et jeunes afro-canadiens, le racisme anti-noir, parents et étudiants noirs, statut socio-économique bas, race et ethnicité, classe sociale 


\section{Introduction}

The article presents the findings of a parent engagement project called "Mentoring Circles." Funded by a small provincial grant, the purpose of the project was to engage low-income Black parents with their local school communities and to support one another. Through mentoring circles, participants were encouraged to share their strategies for navigating the complex school system and to share their experiences of anti-Black racism.

Among racialized groups, Black families are more likely to experience financial insecurity, in large part due to institutional and systemic racism. Although the 2016 census indicated that Ontario's overall poverty rate was $14 \%$, for racialized people, the rate was $21 \%$. For Black Canadians, the poverty rates were 24\% (Statistics Canada, 2020). The factors contributing to these numbers are higher unemployment rates and lower incomes among Black Canadians. In Ontario, the unemployment rates for Black Ontarians was just over $12 \%$, compared to an unemployment rate of $6.7 \%$ for White Ontarians (Statistics Canada, 2020). Black males earned $66 \%$ of White Canadian-born male salaries, while Black women earned $56 \%$ of White female salaries (Statistics Canada, 2020. These racialized income gaps are a consequence of employment discrimination, underemployment, non-recognition of foreign earned credentials, and unequal access to education and training (Livingstone \& Weinfeld, 2015).

In school contexts and communities, parent engagement among low-income families has historically been challenging (Ferlazzo \& Hammond, 2009; Lawson \& Alameda-Lawson, 2012; Latunde \& Clark-Louque, 2016; Mendez, 2010; Murray, 2009; Simons-Morton \& Chen, 2009; Wang et al., 2014). The research shows that Black students are more likely to come from lower-income families (Livingstone \& Weinfeld, 2015; Statistics Canada, 2020). This places them at increased risk of stigmatization and discrimination. Low-income parents may be employed in shift work, part-time work, or contract work that can make it difficult to participate in parent-teacher evenings, parent councils, and other extracurricular activities. Low-income Black parents are unfairly stigmatized as having little or no interest in their children's education (Adjei et al., 2018; Dei et al., 1997; James, 2012; Ladson-Billings, 2006). Low-income children face lower expectations of academic competence from their teachers and are believed to bring additional 
behavioural problems into the classroom (Dei et al., 1997; James, 2012; James \& Turner, 2017; Livingstone \& Weinfeld, 2017; Solomon, 2004).

The findings of this study challenge the dominant conceptualizations of low-income Black parents as being disengaged with school communities. In this study, I sought to explore the strategies used by these parents to support their children's educational success. Few studies have explored how Black parents support each other through mentorship. I argue that mentoring circles could serve as a model for engaging Black parents in the support of their children's academic success. This article will present a brief overview of the scholarly literature on Black student academic achievement and Black parental engagement, the theoretical frameworks, methodological approach taken, and the findings.

\section{Black Student Academic Achievement}

Over the past few decades, scholars have published about the disparities in Black Canadian academic achievement. Black Canadian students have lower rates of high school completion and university degree attainment (Braithwaite, 1989; Codjoe, 2001; Dei et al., 1997; James \& Turner, 2017; Livingstone \& Weinfeld, 2017; Robson et al., 2018; Solomon, 2004).

The existing data show that academic achievement is gendered, with Black Canadian females achieving higher rates of secondary school completion and post-secondary participation than Black Canadian males (George, 2020; Linton \& McLean, 2017; Livingstone \& Weinfeld, 2017; Wane \& Neegan, 2004; Wood, 2006). Black male students are more vulnerable to suspension and expulsion in Ontario schools (James \& Turner, 2017; Saul, 2006; Sibblis, 2014). James (2012) argues that the discourse of "risk" has become a negative label associated with Black youth, specifically Black males, who may be seen by teachers as academic underachievers, fatherless, having only athletic skills, and troublemakers. Deficit discourses tend to frame student failure as an individual and family problem and fail to critique the institutional structures that affect the student (Portelli et al., 2007).

Contributing to these disparities has been the systematic streaming of Black Canadian students into Applied rather than Academic tracks, which limits their post-secondary attainment (James \& Turner, 2017). In July 2020, the Ontario government announced that it would end streaming in the ninth grade and implement a ban on suspending elementary 
school children (Jivani, 2020). Black parents may experience discrimination in the education system and it contributes to the degree of parental engagement that they are able to sustain.

\section{Parent Engagement and Black Children}

The scholarly literature on parent engagement links it to student academic achievement (McGee \& Spencer, 2015). Parental engagement is broadly considered to refer to the active participation of parents/guardians in their school communities (Murray et al., 2014). This involves communication with teachers and involvement in school-related activities (Scanlan \& Johnson, 2015). Murray et al. (2014) add that parental engagement also includes the capacity or ability to dedicate resources and times to their children's schooling. Sylvestre (2018) contends that many models of parent engagement are Eurocentric and do not acknowledge how intersections of class, race, and gender may affect Black parent engagement.

Many researchers have noted how problematic parental engagement can be for Black parents, who have been largely characterized as disengaged (McGee \& Spencer, 2015). James and Turner (2017) assert that a culture of anti-Black racism within a school can negatively affect parental engagement among Black parents. Black parents may be aware of their child's differential treatment at school and this can contribute to an antagonistic relationship between themselves and their child's school (James \& Turner, 2017). In addition, there are complex structural barriers that Black parents face (Livingstone $\&$ Weinfeld, 2015). Powell and Coles (2020) argue that Black parents are perceived as poor parents, in particular if they are single parents living in low-income communities. Low-income Black parents are likely to encounter deficit beliefs about their capacity for parenting and these deficit beliefs affect their children's experiences in school. Perceiving there to be a lack of structure and discipline at home, the school personnel may be more likely to suspend and administer harsher punishments (Anucha et al., 2018; Sibblis, 2014). 


\section{Theoretical Frameworks}

This research article draws on theories of community cultural wealth. In contrast to the deficit framing of Black parents, this article focuses on their strength and community cultural wealth (González et al., 2005; Yosso, 2005). One of the most important, yet simple, premises of the "Mentoring Circles" research project is that Black parents have a rich repository of knowledge, or funds of knowledge (González et al., 2005) that is gained from their distinct life experiences. This approach allows us to view families that have been historically marginalized in terms of their strengths and resources (González et al., 2005). Unfortunately, the very public perceptions of Black families have most often been related to drugs, violence, and other "problems," hence erasing the resiliency, fortitude, and creativity of individuals and communities. Moreover, through counter-storytelling, Black parents can share their stories and strategies that challenge the dominant narratives of deficit (Yosso, 2005).

This article also draws on critical race theory. Critical race theory (CRT) emerged in the aftermath of the US Civil Rights movement. Legal scholars framed the discourse and it has been developed as both a theoretical framework and research methodology (Crenshaw et al., 1995; Delgado \& Stefancic, 2017). Critical race theorists adopt a position known as "racial realism," which holds that racism is a means by which societies allocate privilege and status (Delgado \& Stefancic, 2012). Racial hierarchies exist as fixed entities that determine access to power and prestige. Critical race theory also takes the salience or significance of race as a key predictor of social outcomes. The salience of race refers to the idea that race is an important conceptual category on the basis of which power, prestige, and privilege are rendered meaningful in contemporary society (Delgado \& Stefancic, 2012). The Black parents in this study experienced anti-Black racism within school contexts that promoted policies and practices that had a disparate impact on their Black children.

Given that 14 of the 15 participants were Black women, a Black feminist approach to the interpretation of the findings was adopted. Collins (2000) contends that the primary purpose of Black feminist thought is to resist oppression. Black feminist thought can be regarded as a set of interrelated conceptualizations about Black women's collective consciousness that form a unique standpoint (Collins, 2000). Epistemologically, Black feminist thought also takes seriously the concept of an "ethic of care," in order to 
address the continued subjugation and marginalization of Black women within institutional spaces and beyond (Lykke, 2010). The continued denigration of Black women in the domains of family, popular media, schools, workplaces, and other institutional spaces makes clear the need for solidarity and resistance.

\section{Methodology}

Denzin and Lincoln (2003) define qualitative research as "a situated activity that locates the observer in the world and consists of a set of interpretive, material practices that make the world visible" (p. 4). Creswell (2013) states that qualitative research serves to illuminate the meaning that individuals bring to a phenomenon and allows for a more comprehensive understanding of a phenomenon. Within qualitative inquiry, a phenomenological approach highlights common meanings many individuals can attribute to similar experiences (Creswell, 2013).

I received a small provincial grant for a parent engagement project. I proposed two conduct focus groups as a method of qualitative inquiry. Yin (2011) explains that focus groups are a means of gathering data from similar individuals with shared experiences. I wanted the participants to be able to share their experiences with one another in a safe environment and to share strategies for navigating the educational system.

The location I selected was a region of the Greater Toronto Area identified by the City of Toronto as a "priority" neighbourhood (City of Toronto, 2014). Priority neighbourhoods are underserved communities characterized by lower income, high unemployment, lone-parent families, lack of single detached housing, and lower educational attainment. I recruited parents by posting flyers at local schools and community centres, and distributed them with the help of a local community organizer. After the recruitment phase, I conducted a total of two two-hour focus groups with seven to eight Black parent participants in each group. The parents were given demographic questionnaires and consent forms at the beginning of the session and two research assistants facilitated each focus group. I hired Black women facilitators who were also graduate students in the field of Education. I selected Black women so that the participants would feel more comfortable sharing experiences of racism. The facilitators gathered the consent forms, 
audio-recorded the sessions, and asked the focus group interview questions. As the head researcher I was present at both sessions and assisted with all tasks.

A total of 15 Black parents participated in the focus groups, ranging in age from 28 to 42 . There were 14 Black females and one Black male. The gender imbalance was attributed to the fact that many of the Black women were single parents. Research shows that Caribbean families are three times more likely to be led by a female single parent (Navara \& Lollis, 2009). Those who had partners were likely to shoulder most of the burden of childcare, which included participating in the focus groups. The focus groups were held at a local community centre and the parents were provided with a $\$ 25$ grocery store gift card as a token of appreciation upon completion of the focus group. Free childcare was provided for them in a separate room and everyone received light refreshments. Focus group participants were asked only two questions, and the facilitators moderated the discussion and answered any questions the participants asked. The research questions were: What challenges have you or your children encountered in the school system? What strategies have you used to overcome those challenges?

The following is a summary of the demographic data questionnaire.

\section{Table 1}

Focus Group One (Seven Participants)

\begin{tabular}{lllll}
\hline Participant & Gender & Age & $\begin{array}{l}\text { Number and ages } \\
\text { of children in the } \\
\text { TDSB schools }\end{array}$ & $\begin{array}{l}\text { Household in- } \\
\text { come (after tax) }\end{array}$ \\
\hline Participant 1 & Female & 33 & Four (ages 4, 6, 7, 9) & $\$ 30,000$ \\
Participant 2 & Female & 31 & Two (ages 9 and 10) & $\$ 35,000$ \\
Participant 3 & Male & 41 & One (age 5) & $\$ 35,000$ \\
Participant 4 & Female & 39 & Two (ages 4 and 14) & $\$ 30,000$ \\
Participant 5 & Female & 32 & Three (ages 4, 7, 9) & $\$ 25,000$ \\
Participant 6 & Female & 28 & Three (ages 4, 6, 7) & $\$ 25,000$ \\
Participant 7 & Female & 42 & Two (ages 5 and 8) & Prefer not to say \\
\hline
\end{tabular}


Table 2

Focus Group Two (Eight Participants)

\begin{tabular}{lllll}
\hline Participant & Gender & Age & $\begin{array}{l}\text { Number and ages of } \\
\text { children in the TDSB } \\
\text { schools }\end{array}$ & $\begin{array}{l}\text { Household } \\
\text { income (after } \\
\text { tax) }\end{array}$ \\
\hline Participant 8 & Female & 34 & Two (ages 10 and 16) & $\$ 25,000$ \\
Participant 9 & Female & 41 & Two (ages 14 and 17) & $\$ 35,000$ \\
Participant 10 & Female & 36 & Three (ages 8, 10, 14) & $\$ 20,000$ \\
Participant 11 & Female & 33 & Two (ages 7 and 9) & $\$ 30,000$ \\
Participant 12 & Female & 40 & Four (ages 4, 7, 9, 10) & $\$ 25,000$ \\
Participant 13 & Female & 35 & Three (ages 4, 8, 10) & $\$ 30,000$ \\
Participant 14 & Female & 34 & One (age 6) & $\$ 35,000$ \\
Participant 15 & Female & 38 & Four (ages 5, 8, 11, 13) & $\$ 35,000$ \\
\hline
\end{tabular}

\section{Data Analysis}

The data analysis was primarily focused on focus group interview data. For general analysis, I utilized the cross-case analysis method described by Stake (2006). Common themes were identified across both cases and refined into what Stake (2006) describes as “assertions," which constitute one's findings. As Stake (2006) argues, it is important not only to examine the similarity between cases, but also the differences. I also sought to discover differences through the analysis of the data. The key function of cross-case analysis is to analyze each case and apply the findings to the initial research questions (Stake, 2006).

For the interview data, I utilized methods of thematic narrative analysis (Riessman, 2008). Riessman (2008) explains that thematic analysis differs from structural analysis in that the emphasis is on "the told" rather than the manner of "telling." With thematic analysis, there is less attention given to the subjective elements of speech production than the content of the speech. I do recognize, as Riessman contends, that my interpretations were guided by my theoretical approach. I believe that these methods allowed me to generate rich data about the complexities of Black parent experiences. Clandinin and Connelly (2000) argue that narrative values people's lived experiences. 
The focus group data were coded using the Atlas Ti software program. The Atlas Ti software program allows the user to complete line-by-line coding of the data. This software program also permits the tracking of co-occurring codes and the creation of a family of codes. Creating a family of codes allowed me to identify themes in the focus group data. Coding began after interviews with the first focus group were transcribed. After the focus groups were completed, all participants were emailed a transcript and provided with the opportunity to redact any statements they may have made. Only one participant elected to redact some information that may have identified them.

I followed Saldana's (2009) system of first and second cycle coding. The first cycle of coding was descriptive and the second cycle of coding was thematic. Codes were analyzed and grouped into central themes across both focus groups. This article will focus on the two themes of "sistah mentorship" and "advocating for their children through relationship-building."

\section{Findings}

Theme 1: "Sistah Mentorship." Informal mentoring networks. The overwhelming majority of the participants were Black mothers. When asked about strategies to overcome the challenges they faced, most of the participants revealed that they relied on informal networks of "sistah" friends who they could call for advice if they encountered a problem with their child's school. Collins (2000) argues that African-American women face an ongoing struggle to maintain their humanity in the face of oppression. In order to accomplish this, Black women form kinship bonds of care to support each other. Othermothering has been described by Collins (2000) as an African-American, community-based parenting strategy whereby members care for the biological children of others. This ethic of care includes the provision of educational, material, and emotional support. I argue that the Black women in the focus groups provided caring relationships to their female friends as well as their children. The ethic of care typified by othermothering among African-American women is rooted in an African humanism that values both self and community care (Collins, 2000). African humanist traditions value community and family relationships. Not all participants shared stories about their personal networks of Black mothers, but when the facilitator posed a probing question about their reliance 
on informal mentorship networks, all six of the women in the first focus group raised their hands and so did six of the women in the second focus group. Their "sistah" friends were Black mothers who had children in one of the Ontario school boards. Participant 11 explained:

I just call my girlfriend who has kids a little older than mine. She has been through the system and doesn't stand for any nonsense. You have to be prepared when you meet with the teachers because they try to put you down.

Facilitator 1: So you rely on your friends?

Participant 11: Yes! If they are doing something at the school... I do not know. One time I had a problem with the teacher and I asked her [friend] to come with me. You know strength in numbers. These teachers think we're uneducated so they treat us a certain way. I want to show them that I am not alone so they can't just walk all over me.

Participant 11 noted that her friend was part of her informal support system. She asserts that her friend does not "stand for any nonsense" in a manner that seems to express admiration. As she learned from her friend, she has to be prepared when dealing with teachers from her children's school because she is hyper-aware that they are predisposed to having a bias against her because of her lack of formal education and her single parent status.

The Black male participant in the first focus group mentioned that when he appeared at the school with his wife, the tone of the conversation would become more collegial because of the stereotype that the low-income Black mother was a single parent. The Black male participant was also aware of how the Black mothers were perceived by teachers and the school administration. His presence also challenged dominant stereotypes of the absent, irresponsible, Black father (James, 2012; Saul, 2006).

For one immigrant mother, her support network of Black mothers helped her to navigate an unfamiliar school system. She expressed her frustration about the policies:

When I just came to Canada, I did not know about the system so I had to ask so many friends...is this right? Is this what the policy is? The system here is so 
different from back home. When my son was suspended, I did not understand why. Why keep him at home? I did not understand the policies. (Participant 14)

Many researchers have found that Black students face higher rates of school suspensions and other forms of discipline (James \& Turner, 2017; Sibblis, 2014; Winton, 2013). Many of the parents in both focus groups shared their concerns about school discipline practices. They were aware of that their children were more likely to face disproportionate rates of school discipline and sought each other out for support and information.

Perceptions of the Individualized Education Plan. These networks of Black mothers were supportive, but did not always provide accurate information to the participants. The most contentious issue was the Individualized Education Plan or IEP. The focus group participants expressed their disapproval of the IEP process. Through their personal networks, many had received messages from their peers that IEPs would be detrimental to their child's future. Given that the research team included licensed Ontario teachers, the focus group facilitator stepped in to explain the purpose and value of IEPs and added that it would help their child access additional resources and support. Many of the Black mothers remained unconvinced because they heard many negative stories from their peer networks. This was one opportunity for the participants to help each other by sharing critical information about a process they perceived to be confusing.

James and Turner (2017) reported that Black students were more likely to be identified as having exceptionalities that require an IEP.

For lower-income families, assessment processes involve long wait times. Middle-class or higher-income earners are able to pay thousands of dollars for an assessment. One Black mother complained:

It's a long ass wait list. And I was like, well, I can't wait that long to help now. So, then I found a place in Durham region that did it for free. That's a good thing. I believe you have to pay if once they're diagnosed. And so, because she was diagnosed, diagnosed at 16,17, it was hard for her to get used to the fact that she had an IEP because she wants to be at that age, like her friends. She'd liked getting extra time for her homework. That's good. But I did that. And for me, honestly, I had no problem with the IEP simply because, I knew that going into grade 11 and 12 , she needed that support because that's University/College time. (Participant 9) 
While this participant described the IEP process positively, there was disagreement among the Black parents. Some parents believed that IEPs were a means of labelling their children as deficient. Some parents asked the facilitators and myself what their legal rights were to refuse an IEP. They also wanted assurances that having an IEP would not disqualify their children from pursuing post-secondary education. Participant 9 was keenly aware that the later years in high school were critical to accessing post-secondary education and wanted to ensure that her child had the best opportunities possible. Schools could increase trust and understanding about the IEP process with more dialogue with parents about the IEP process, including providing information sessions and organizing meetings to discuss IEPs.

Experiences of racism. As the literature review has illustrated, systemic racism in the school system is all too prevalent. One of the areas that Black mothers relied on each other for support concerned how to navigate systemic racism. Most of the parents talked about how racism affected their relationship with school personnel. The majority of the Black parents in both focus groups perceived that they had experienced racism from some of the teachers and school administrators. This was evidenced by experiences of differential treatment such as suspensions and detentions for their children. In addition, the tone of voice and other non-verbal behaviors that they experienced when engaging with school personnel served as racial microaggressions. Sue (2010) describes microaggressions as verbal or non-verbal insults that are targeted at a member of a marginalized group. One mother was very outspoken about the fact that she believed that some teachers in her daughter's school were overtly racist:

There are some teachers that need to retire. They're racist. I will tell you straight out... So when I do see the White racist teacher and then they want to tell me they're not racist. I'm like, don't tell me because I can see it. I see the discrimination. I see the way you treat certain people... (Participant 5)

Critical race theorists argue that racial realism means that Black people can perceive covert and subtle forms of racism directed at them regardless of whether the perpetrator recognizes it as such (Delgado \& Stefancic, 2012). Recognizing that the Black parent account here is one of perception, it is nevertheless important to understand why they might be left with such an impression. All of the participants in focus group one 
nodded their heads to indicate their understanding about the implications of race in the school environment. It appeared to the facilitators that they were resigned to dealing with everyday racism. It is important to consider how the intersections of race and class might further influence their perceptions. One participant from the first focus group described acts of racism that took the form of racial microaggressions (Sue, 2010).

This Black mother described one of several incidents where she perceived herself to be disrespected by the school staff and administration. She was not greeted and was instead ignored by the school staff. She interpreted this as a sign of disrespect. This type of interaction becomes part of a cyclical pattern of mistrust between the teacher, school staff and the parent. According to Sue (2010), ignoring an individual in a deliberate manner is a microinvalidation of their presence. Sue (2010) aligns microinvalidations with color-blind racism (Bonilla-Silva, 2014) in which the perpetrator claims not to "see" the racism or issue. In this instance, the Black parent was visibly concerned, and she was ignored.

Another focus group participant described an incident that involved physical violence by a White teacher enacted upon a Black child. Describing the incident in detail could identify the school and the parent because of the ongoing complaint filed by the parent and subsequent investigation. Based on their narratives and field notes taken during the session, most of the focus group participants have experienced racism directed at them and their children in the school system. Their strategies for navigating the school system included seeking the support of other Black mothers who had similar experiences. As Collins (2000) contends, Black feminist othermothering involves the radical care of more than just one's own children, but concern for the children of other Black mothers. The findings from theme one show that there is a need for continuing anti-Black racism and equity training in order to foster positive relationships between Black parents and schools.

\section{Theme 2: Advocating for Their Children through Relationship-Build- ing: Black Parents as Power Brokers}

The focus group facilitators asked the parents which positive strategies they had developed to successfully navigate their children's school. The most common strategy they shared was maintaining open lines of communication with their child's teacher and 
school. They believed that this was one of the best ways to advocate for their children. The following excerpt describes how the mother plans to form a positive relationship with the teachers early on and how this would help to counter any negative preconceptions they may have about her child.

So I feel this year, I'm going to make sure I meet the teachers from day one. I will come across polite, but I will let them know. I will put my foot down. There's a certain way I expect you to treat my child. And if my child is misbehaving, we nip it in the bud. But I find that when they already labelled your son from the year prior, you don't have a new opportunity, no matter what you say, no matter what you do...they don't care... (Participant 7)

While she explained what her strategy was, she also asserted that it would not work if her child had been labelled negatively by the school administration. In her mind, this would be too difficult to overcome. A key element of her narrative is her self-perception regarding how the intersections of race, gender, and social class may frame her as an "Angry Black Woman." She mentioned that she planned to "come across as polite."

Collins (2000) observes that racist and sexist stereotypes about Black women influence their everyday lives. Scholarly literature has catalogued the negative images of Black women that are present in the media. The negative images contribute to the denigration of Black women in a way that stigmatizes them within institutional settings. Black women are seen as less worthy of sympathy. Collins (2000) asserts that Black women are portrayed by the media as "bad mothers" who are domineering, verbally abusive, and selfish. It is through this lens that both teachers and child welfare authorities perceive the parenting of Black mothers (Adjei \& Minka, 2018; Hackett, 2017). In the second focus group, one mother also shared her strategy of establishing positive communication with her children's school.

So not every parent [has] the time that they can come to school for every little thing. But if you set the tone at the very beginning of the year, that again, you're a power because when they call you, you can say, did you remember when we met and what we spoke about? (Participant 12) 
The participant explained above that she needed to "set the tone" by meeting with the teacher early in the semester and perceived that it might give her an upper hand when dealing with later challenges.

One Black mother explained that she was actively involved in her child's school:

I'm in that school at least twice a week. And yes, I do work full time. I'm on email and I'm always calling, and I write letters and notes, a superintendent every month, I'm fully in there. Like I walk into the school and the kids know! (Participant 2)

The above quote illustrates how one Black mother made serious, engaged efforts to become involved in her child's school. In spite of her full-time employment status, she told the other focus group participants that she is well known by the school staff and students. It became clear that the focus group participants believed that school involvement was one strategy of resistance and agency. Another Black mother gave advice to her fellow focus group participants about strategies for effective advocacy:

I always read the newsletters and the school website and the TDSB website. When I speak with the teachers I mention what I read so they know I am involved...that I want to be involved. I can see the surprise on their faces when I tell them what I read. (Participant 10)

It was not surprising that many of the focus group participants were distrustful of the Ontario school system. Participant 8 discussed academic streaming practices that limited Black student access to Advanced-level courses for decades that have only recently been changed (Jivani, 2020). As the mother correctly argued, if parents realize too late that their child has been streamed into Applied/General/Workplace it may prevent them from accessing university-level education. Recent immigrants are particularly vulnerable to this practice because they do not have sufficient experience with the Ontario education system to understand or recognize the differences. Black parents may need to advocate for their children by attempting to form positive relationships with their children's schools and teaching themselves as much as possible about school policies and practices. These strategies may help to ensure that their children are positioned for academic success. 


\section{Discussion}

In general, the findings challenge stereotypes about low-income Black parents by illustrating that they are heavily invested in their children's academic excellence. It is a widely held misconception that low-income parents have little value for education, but this study's findings support others by showing that Black parents are very encouraging and support the academic success of their children (Adjei et al., 2018; Linton \& McLean, 2017; Murray, 2009). The participants were uniquely affected by both racial and social class marginalization. The intersections of race and class provide an interesting angle to this study. The original research questions asked about the experiences and strategies employed by the Black parents. The findings were that they cultivated social networks of "sistah mentors" who were similarly positioned Black women they could turn to for advice. They also advocated for their children by establishing relationships with their children's teachers.

The results also speak to the importance of the community cultural wealth model espoused by González et al. (2005) and Yosso (2005). The narratives of the participants illustrated that they possessed a wealth of cultural and community knowledge that they used to help their children and their communities. A complex intersection of cultural and structural barriers alienated these Black parents from their children's schools.

The results support the theoretical frameworks of Black feminist practices around the "ethic of care" that Black women employ to support each other (Collins, 2000). The Black mothers in the study had the positive presence of at least one Black mother whom they could rely on to help them navigate the school system. While the findings suggest that the participants experienced this positively, this may be not be appropriate for all Black women. A known critique of othermothering is that it may reinforce the "strong Black woman" archetype, which may further subjugate Black mothers. Black feminist thought presents a challenge to White dominant stereotypes about the "strong" Black woman or "superwoman" (Collins, 2000). These dominant archetypes shift the burden from the societal forms of oppression and racism that impact Black women's lives to the individual Black woman who must be "strong enough" to cope. In addition, the "strong Black woman" myth suggests that women should voluntarily take on the additional responsibilities in their school, work, and social communities. For Black women who 
choose to othermother, they should be supported to ensure their emotional and physical well-being.

The results speak to the need for cultural and structural supports. There is a need for what Ladson-Billings $(1995,2013,2014)$ has termed culturally relevant pedagogy, which is an educational approach that sets high expectations for the academic achievement of marginalized children and values the cultural backgrounds of the students. The school system can be interrogated as a space of White hegemonic norms and biases. In that context, there is a need for what Daniel and Jean-Pierre (2020) have referred to as Black-affirming spaces. Black-affirming spaces support the social identities of Black children and their parents. Mentoring circles of Black mothers exemplify such Black-affirming spaces. Di Virgilio (2013) observed that minority-serving institutions in Canada arose out of many decades of debates about the issue of segregation and inclusivity. This has been addressed primarily through public-school board initiatives such as the Africentric School and other publicly funded schools for students from LGBTQ+ or Indigenous backgrounds (Howard \& James, 2019; Toronto District School Board, 2018; Washington, 2020). There needs to be additional board-wide efforts to support Black parents and students in all the schools. The findings also address the need for structural supports for low-income families related to assessment for exceptionalities, information about individualized education plans, and resources support for school policies and practices (Ferlazzo \& Hammond, 2009).

Despite the findings, there were several limitations of this study. All participants self-selected, so their perspectives may not be representative of the low-income Black parent population in general. This qualitative study with two focus groups' findings and a purposive sample are not generalizable. The other major limitation was that more attempts could have been made to find more Black male fathers to participate in the focus groups. Outreach to Black fatherhood community groups might have yielded more Black male participants. Nevertheless, the focus group participants engaged in what Solórzano and Yosso (2002) refer to as "counter storytelling," whereby Black parents were able to challenge dominant conceptualizations and stereotypes by exercising their own agency in the support of their children. 


\section{Recommendations}

1. Schools should support informal Black parent support networks through the provision of information about school policies and practices along with resource supports.

2. Schools should provide comprehensive information to parents about the Individualized Education Plan process and disseminate as much information as possible through targeted communications such as newsletters, parent information sessions, and social media. Efforts should be made to ensure that parents understand the purpose and implications of the Individualized Education Plan.

3. School board personnel should participate in ongoing anti-Black racism training and awareness so that Black parents do not experience stereotypes about their parenting skills or stereotypes about their engagement with their child's education.

4. Schools should be proactive in fostering effective outreach and communication strategies to engage Black parents so that they do not feel excluded from their child's school community.

\section{Conclusion}

Given the multitude of barriers faced by low-income Black parents, they can strategize for their children's success by forming informal support networks to share community cultural and educational wealth. They can also ensure that they maintain effective communications with their children's school. This does not absolve society of the need to dismantle White supremacy and other structural barriers, but it is a complementary approach that has benefits for Black families. The mentorship networks should be more formally entrenched within Black community organizations. Existing networks benefit those who already possess the financial and social capital to access the resources that their children need.

The findings indicate that low-income Black parents are willing and able to exercise their own agency in holding the school accountable for their children's success. These practices provide a way forward for Black Canadian parents who must navigate anti-Blackness in schools and other institutional spaces. 


\section{References}

Adjei, P. B. (2018). The (em)bodiment of blackness in a visceral anti-black racism and ableism context. Race, Ethnicity \& Education, 21(3), 275-287.

Adjei, P. B., \& Minka, E. (2018). Black parents ask for a second look: Parenting under "White" child protection rules in Canada. Children \& Youth Services Review, 94, $511-524$.

Adjei, P. B., Mullings, D., Baffoe, M., Quaicoe, L., Abdul-Rahman, L., Shears, V., \& Fitzgerald, S. (2018). The "fragility of goodness": Black parents' perspective about raising children in Toronto, Winnipeg, and St. John's of Canada. Journal of Public Child Welfare, 12(4), 461-491.

Anucha, U., Srikanthan, S., Siad-Togane, R., \& Galabuzi, G. E. (2018). Doing right together for Black youth: What we learned from the community engagement sessions for the Ontario Black Youth Action Plan. Youth Research and Evaluation eXchange (YouthREX). https://youthrex.com/wp-content/uploads/2018/07/ YouthREX-Report-Doing-Right-Together-for-Black-Youth.pdf

Bonilla-Silva, E. (2014). Racism without racists: Color-blind racism and the persistence of racial inequality in the United States. Rowman \& Littlefield.

Brathwaite, K. S. (1989). The black student and the school: A Canadian dilemma. In S. Chilungu \& S. Niang (Eds.), African continuities/L'Heritage Africain (pp. 195221). Terebi.

City of Toronto. (2014). Neighbourhood Improvement Area Profiles. https://www. toronto.ca/city-government/data-research-maps/neighbourhoods-communities/ nia-profiles/

Codjoe, H. M. (2001). Fighting a "public enemy" of black academic achievement - the persistence of racism and the schooling experiences of black students in Canada. Race Ethnicity and Education, 4(4), 343-375.

Clandinin, D. J., \& Connelly, F. M. (2007). Mapping a landscape of narrative inquiry: Borderland spaces and tensions. In D. J. Clandinin (Ed.), Handbook of narrative inquiry: Mapping a methodology. Sage. 
Collins, P. H. (2000). Black feminist thought: Knowledge, consciousness, and the politics of empowerment. Routledge.

Crenshaw, K. (1991). Mapping the margins: Intersectionality, identity politics, and violence against women of color. Stanford Law Review, 43(6), 1241-1299.

Crenshaw, K., Gotanda, N., Peller, G., \& Thomas, K. (Eds.). (1995). Critical race theory. New Press.

Creswell, J. W. (2013). Qualitative inquiry and research design: Choosing among five approaches (3rd ed.). Sage.

Daniel, B.-J., \& Jean-Pierre, J. (2020). Re-imagining child and youth care practice with African Canadian youth. International Journal of Child, Youth \& Family Studies, $11(2), 25-39$.

Dei, G. J. S., Mazzuca, J., \& McIsaac, E. (1997). Reconstructing 'dropout': A critical ethnography of the dynamics of Black students'disengagement from school. University of Toronto Press.

Delgado, R., \& Stefancic, J. (2012). Critical race theory: An introduction. New York University Press.

Denzin, N., \& Lincoln, Y. (2003). The landscape of qualitative research: Theories and issues. Sage.

Di Virgilio, A. (2013). Segregation versus inclusion: Understanding minority serving higher education institutions in the U.S. and Canada. College Quarterly, 16(1). http://collegequarterly.ca/2013-vol16-num01-winter/divirgilio.html

Ferlazzo, L., \& Hammond, L. A. (2009). Building parent engagement in schools. Linworth Books/Libraries Unlimited.

George, R. C. (2020). Holding it down? The silencing of Black female students in the educational discourses of the Greater Toronto Area. Canadian Journal of Education, 43(1), 32-58.

González, N., Moll, L. C., \& Amanti, C. (2005). Funds of knowledge: Theorizing practices in households, communities, and classrooms. Lawrence Erlbaum.

Hackett, V. C. R. (2017). African Caribbean migration: A better life. Affilia: Journal of Women \& Social Work, 32(3), 407-412. 
Howard, J., \& James, C. (2019). When dreams take flight: How teachers imagine and implement an environment that nurtures Blackness at an Africentric school in Toronto, Ontario. Curriculum Inquiry, 49(3), 313-337. https://doi.org/10.1080/03 $\underline{626784.2019 .1614879}$

James, C. E. (2012). Students "at risk": Stereotypes and the schooling of Black boys. Urban Education, 47(2), 464-494.

James, C. E., \& Turner, T. (2017). Towards race equity in education: The schooling of Black students in the Greater Toronto Area. York University. https://youthrex. com/report/towards-race-equity-in-education-the-schooling-of-black-students-inthe-greater-toronto-area/

Jivani, J. (2020, July 9). Suspensions and streaming disadvantage Black students. Policy changes mark good first step, Jamil Jivani says. The Brockville Recorder and Times. https://www.pressreader.com/canada/ottawa-citi zen/20200708/281659667331060

Ladson-Billings, G. (1995). Toward a theory of culturally relevant pedagogy. American Educational Research Journal, 32(3), 465-491.

Ladson-Billings, G. (2006). It's not the culture of poverty, it's the poverty of culture: The problem with teacher education. Anthropology \& Education Quarterly, 37(2), 104-109.

Ladson-Billings, G. (2013). Dreamkeepers: Successful teachers of African American children. Wiley.

Ladson-Billings, G. (2014). Culturally relevant pedagogy 2.0: A.k.a. the remix. Harvard Educational Review, 84(1), 74-84.

Lalonde, R. N., Jones, J. M., \& Stroink, M. L. (2008). Racial identity, racial attitudes, and race socialization among black Canadian parents. Canadian Journal of Behavioural Science, 40(3), 129-139.

Latunde, Y., \& Clark-Louque, A. (2016). Untapped resources: Black parent engagement that contributes to learning. The Journal of Negro Education, 85(1), 72-81.

Lawson, M. A., \& Alameda-Lawson, T. (2012). A case study of school-linked, collective parent engagement. American Educational Research Journal, 49(4), 651-684. 
Linton, R., \& McLean, L. (2017). I'm not loud, I'm outspoken: Narratives of four Jamaican girls' identity and academic success. Girlhood Studies, 10(1), 71-88.

Lincoln, Y., \& Guba, E. (2006). Naturalistic inquiry. Sage.

Livingstone, A.-M., Celemencki, J., \& Calixte, M. (2014). Youth participatory action research and school improvement: The missing voices of Black youth in Montreal. Canadian Journal of Education, 37(1), 283-307.

Livingstone, A. -M., \& Weinfeld, M. (2015). Black families and socio-economic inequality in Canada. Canadian Ethnic Studies, 47(3), 1-23.

Livingstone, A. -M., \& Weinfeld, M. (2017). Black students and high school completion in Quebec and Ontario: A multivariate analysis. Canadian Review of Sociology, 54(2), 174-197.

Lykke, N. (2010). Feminist studies: A guide to intersectional theory, methodology and writing. Routledge.

McCarthy Foubert, J. (2019). 'Damned if you do, damned if you don't:' Black parents' racial realist school engagement. Race Ethnicity and Education, 1-18. https://doi. org/10.1080/13613324.2019.1631782

McGee, E., \& Spencer, B. M. (2015). Black parents as advocates, motivators, and teachers of mathematics. The Journal of Negro Education, 84(3), 473-490.

Mendez, J. L. (2010). How can parents get involved in preschool? Barriers and engagement in education by ethnic minority parents of children attending head start. Cultural Diversity and Ethnic Minority Psychology, 16(1), 26-36.

Murray, C. (2009). Parent and teacher relationships as predictors of school engagement and functioning among low-income urban youth. The Journal of Early Adolescence, 29(3), 376-404.

Murray, K. W., Finigan-Carr, N., Jones, V., Copeland-Linder, N., Haynie, D. L., \& Cheng, T. L. (2014). Barriers and facilitators to school-based parent involvement for parents of urban public middle school students. Sage Open. https://doi. org/10.1177/2158244014558030 
Navara, G. S., \& Lollis, S. (2009). How adolescent children of African Jamaican immigrants living in Canada perceive and negotiate their roles within a matrifocal family. Family Process, 48(3), 441-458.

Ontario Human Rights Commission. (2018). Interrupted childhoods: Overrepresentation of Indigenous and Black children in Ontario child welfare. http://www.ohrc.on.ca/ en/interrupted-childhoods

Portelli, J. P., Shields, C. M., \& Vibert, A. B. (2007). Toward an equitable education: Poverty, diversity and students at risk. https://www.oise.utoronto.ca/cld/UserFiles/ File/Toward an_Equitable Education.pdf

Powell, T., \& Coles, J. (2020). "We still here": Black mothers' personal narratives of sense making and resisting antiblackness and the suspensions of their Black children. Race Ethnicity and Education, 24(1), 76-95. https://doi.org/10.1080/136 $\underline{13324.2020 .1718076}$

Riessman, C. K. (1993). Narrative analysis. Sage.

Riessman, C. K. (2008). Narrative methods for the human sciences. Sage.

Robson, K., Anisef, P., \& George, R. C. (2018). Under-represented students and the transition to post-secondary education: Comparing two Toronto cohorts. Canadian Journal of Higher Education, 48(1), 39-59.

Saldana, J. (2009). The coding manual for qualitative researchers. Sage.

Saul, R. (2006). How black male student athletes get stereotyped in Canada's schools. Our Schools/Our Selves, 15(2), 91-109.

Scanlan, M., \& Johnson, L. (2015). Inclusive leadership on the social frontiers. In G. Theoharis \& M. Scanlan (Eds.), Leadership for increasingly diverse schools (pp. 162-185). Routledge.

Sibblis, C. (2014). Expulsion programs as colonizing spaces of exception. Race, Gender \& Class, 21(1/2), 64-81.

Simons-Morton, B., \& Chen, R. (2009). Peer and parent influences on school engagement among early adolescents. Youth \& Society, 41(1), 3-25.

Solórzano, D. G., \& Yosso, T. J. (2002). Critical race methodology: Counter-storytelling as an analytical framework for education research. Qualitative Inquiry, 8(1), 23-44. 
Stake, R. (2006). Multiple case study analysis. The Guilford Press.

Solomon, R. P. (2004). Schooling in Babylon, Babylon in school: When racial profiling and zero tolerance converge. Canadian Journal of Educational Administration and Policy, 33, 1-13. https://files.eric.ed.gov/fulltext/EJ848233.pdf

Statistics Canada. (2020). Data tables, 2016 Census. https://www150.statcan.gc.ca/n1/ pub/89-657-x/89-657-x2020002-eng.htm

Sue, D. (2010). Microaggressions in everyday life: Race, gender, and sexual orientation. Wiley.

Sylvestre, D. (2018). Parent engagement and schooling: Examining Black parents' experiences in the Greater Toronto Area [Unpublished master's thesis]. University of Toronto.

Toronto District School Board. (2018). Oasis Alternative Secondary School. https://www. tdsb.on.ca/Find-your/Schools/schno/5584

Wane, N. N., \& Neegan, E. (2004). African Canadian high school girls and their quest for education. Orbit, 34(1), 36-38.

Wang, M., Hill, N. E., \& Hofkens, T. (2014). Parental involvement and African American and European American adolescents' academic, behavioral, and emotional development in secondary school. Child Development, 85(6), 2151-2168.

Washington, S. (2020). Sustaining Indigenous students' and families' well-being and culture in an Ontario school board. Journal of Professional Capital and Community. Advance online publication. https://doi.org/10.1108/JPCC-06-2020-0049

Winton, S. (2013). From zero tolerance to student success in Ontario, Canada. Educational Policy, 27(3), 467-498. https://doi.org/10.1177/0895904812453994

Wood, M. (2006). Storying experiences: Black Canadian girls and schooling. [Unpublished doctoral dissertation]. York University.

Yin, R. (2011). Qualitative research from start to finish. The Guildford Press.

Yosso, T. (2005). Whose culture has capital? A critical race theory discussion of community wealth. Race Ethnicity and Education, 8(1), 69-91. 